\title{
The implementation for natural science online lecture with chemistry education base at Nurul Fadhillah school Bandar Setia
}

\author{
Zainuddin Muchtar ${ }^{1}$, Sri Adelila Sari ${ }^{1}$, Siti Rahmah, ${ }^{1, *}$, Moondra Zubir ${ }^{1}$, \\ Rini Selly ${ }^{1}$ and Marini Damanik ${ }^{1}$ \\ ${ }^{1}$ Department of Chemistry, Universitas Negeri Medan, Medan 20221, Indonesia \\ *Corresponding author: SR, rahmah.siti@unimed.ac.id
}

DOI: 10.24114/jpkim.v13i1.24212

Article history:

Received: 16 November 2021

Revised: 31 March 2021

Accepted: 05 April 2021

\begin{abstract}
The Covid-19 pandemic forces learning activities to change from classroom learning to online-based learning. Based on the results of the interview, it was found that the teachers at Nurul Fadhilah school did not yet have the readiness to manage online teaching and learning activities, especially in science subjects. The influencing factors are (1) understanding of basic science concepts (physics, chemistry, biology), (2) understanding of systematic online learning management and (3) mastery of Learning Management System (LMS) technology. Therefore, the aim of this activity is to implement LMS technology in the management of online science learning using a basic conceptual approach to chemistry education. LMS is a technology application developed specifically for managing classrooms, distributing learning materials and enabling collaboration between students and teachers online. The LMS used in this activity is Google Classroom. Based on the data, it is known that $65 \%$ of the teachers at Nurul Fadhilah School have not managed online science teaching and learning activities using LMS technology. The results of the systematic online science learning management workshop using the basic concepts of chemistry education and the implementation of LMS technology, especially Google Classroom, showed an increase, as many as $80 \%$ of teachers have created, designed and managed classes interactively using Google Classroom LMS technology and have integrated the concept of basic chemistry education in science learning. So that students are more happy and comfortable in learning online and are more disciplined in collecting assignments and teachers are more comfortable in managing and evaluating student assignments.
\end{abstract}

Keywords: Natural science, Learning management system, Google classroom

\section{Introduction}

Technological developments change classroom learning into online-based learning. Istiningsih and Hasbullah (2015) stated that blended learning is a learning 
strategy that is appropriate to use in the future considering the development of technology and communication in Indonesia is very adequate. Blended learning is a combination of face-to-face learning and online learning using Learning Management System (LMS) technology. Learning Management System is a technology application developed specifically for managing classrooms, distributing learning materials and enabling collaboration between students and teachers online.

Since the Covid-19 pandemic attacked Indonesia, teaching and learning activities have been forced to be completely carried out online. Online learning requires readiness, including (1) student readiness, (2) teacher readiness, (3) infrastructure, (4) management support, (5) school culture and (6) face-to-face learning (Jamal, 2020). Handayani et al. (2020) stated that the readiness of students includes (1) technology readiness (smartphone), (2) physical readiness (a healthy body) and readiness for learning resources (thematic books). According to Prabowo et al. (2020) teacher readiness in online learning is influenced by several factors, such as institutional support in providing online learning training to the teachers and teacher self-directed learning.

Natural Science teachers need competence and skills in creating, designing and managing natural science lessons online. Because natural science learning requires mastery of basic natural science concepts (Chemistry, Physics, Biology), mastery of critical and analytical thinking, and mastery of exploration of natural phenomena. According to Hotimah and Muhtadi (2018) in studying natural science, students are more interested in making observations and experiments in the surrounding environment. The habit of face-to-face learning by conducting experiments directly in the laboratory or outdoors is one of the obstacles for teachers to develop interactive natural science learning online. In addition, the teacher's ability to master LMS technology also plays an important role in creating interactive online natural science learning so that learning outcomes are achieved.

Interactive online learning must involve student interaction with teachers through electronic media (Hotimah and Muhtadi, 2018; Harefa et al. 2020). The advantage of online learning is that teaching and learning activities are not limited to space and time. However, the readiness of teachers and students to utilize technology is important in the process. Based on interviews with the principal Nurul Fadhilah School, it was found that teachers at the Nurul Fadhilah School had implemented online teaching and learning activities. However, mastery of basic natural science concepts and mastery of technology in managing natural science online learning is still weak. In teaching and learning activities, teachers have not utilized the Learning Management System technology. Teachers only use the WhatsApp application, which is chat-based social media in teaching and learning activities. In addition, it was found that the teacher's ability to design and integrate natural science learning materials online was still low. Therefore, this activity aims to implement LMS 
technology in the management of online natural science learning using a basic conceptual approach to chemistry education.

\section{Methods}

This activity was conducted at the at the Nurul Fadhilah School, which is located in Bandar Setia Village, Percut Sei Tuan, Deli Serdang, North Sumatra. The population of this activity is 54 teachers from all level in Nurul Fadhilah School. This activity is carried out in three stages:

\subsection{Method observation}

The team from the LPPM Universitas Negeri Medan collaborated with Principal of Nurul Fadhilah School to discuss problems faced by teachers at Nurul Fadhilah School. Then, the LPPM Team looked for solutions to overcome these problems using the basic knowledge possessed by the team, namely Chemistry Education.

\subsection{Method implementation}

The method was used in this activity is online science learning management workshop using a basic concept approach to chemistry education by two speakers from the LPPM team, namely Dr. Zainuddin Muchtar, M.Si and Dr. Sri Adelila Sari, M.Si. Then, the implementation of the use of LMS technology in creating, designing and managing natural science learning online. At this stage, the training participants (Nurul Fadhilah School teachers) were divided into 3 small groups and given direct training in the management of natural science learning using the LMS Google Classroom by instructors from the LPPM team.

\subsection{Method responses analysis}

Initially, each participant was given a pretest to find out the participants' initial understanding. Then, participants were given a guidebook for using the Google Classroom LMS as teaching material in training. Participants are given the opportunity to practice hands-on to create classes, submit natural science subject matter, and manage natural science teaching and learning activities interactively using Google Classroom LMS technology. At the end of the activity, the participants were given a posttest to determine the increase in understanding of each participant in the management of online science learning. Regular monitoring and evaluation was also carried out as a follow-up to this activity.

\section{Results and Discussion}

The identification of problems faced by Nurul Fadhilah School since the implementation of online learning activities by the government shows that teachers do not have readiness in managing science teaching and learning activities online. 
The influencing factors are (1) understanding of basic science concepts (physics, chemistry, biology), (2) understanding of systematic online learning management and (3) mastery of Learning Management System (LMS) technology. Teachers at Nurul Fadhilah school have not implemented the use of LMS technology in online science teaching and learning activities. So far, teachers have only used the WhatsApp application in science learning activities, which is a chat-based social media application. The whatsapp application is not the right application to be used in science teaching and learning activities because it is not an LMS.

Online learning which is applied at Nurul Fadhilah School, namely: (1) The teacher sends materials and assignments that must be done by students through the WhatsApp application, and (2) students collect assignments that have been done through the WhatsApp application. The problem is the WhatsApp application requires a large enough media storage space, while the capacity provided depends on the sophistication of smartphone technology owned by students and teachers. So that often the learning material and assignments that have been collected by students are deleted from the smartphone storage space. In addition, the WhatsApp application also has limitations for face to face in real time through its features and has not been able to provide a time limit so that students do not submit assignments beyond the predetermined time limit (Bhagaskara et al. 2021). This is less effective in learning activities because the WhatsApp application is not an application designed

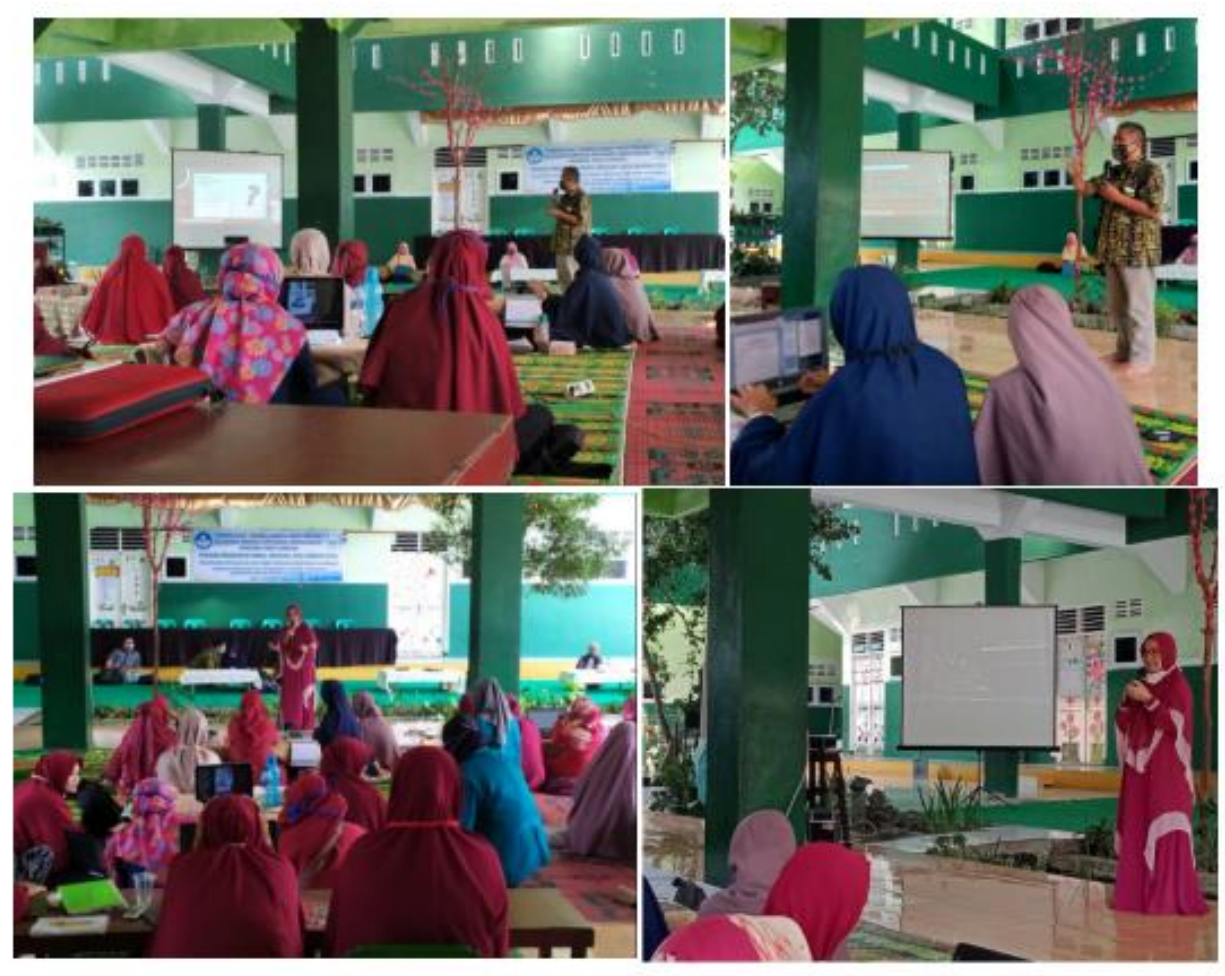

Fig 1. Workshop natural science online lecture 
as a learning management system. In addition, teachers' mastery of basic science concepts (physics, chemistry and biology) also tends to be low. Whereas based on the curriculum, students must be taught basic science concepts from the elementary school level. Mastery of basic science concepts influences teacher creativity in creating and designing interactive classes. Because teaching and learning activities require interaction between students and teachers. Both teachers and students must play an active role so that learning outcomes can be achieved.

Based on this phenomenon, the LPPM team at the State University of Medan tried to provide solutions to solve the problems faced by teachers at Nurul Fadhilah School. Based on the results of the Focus Group Discussion, the LPPM team at the State University of Medan provided an understanding of LMS technology in the management of online science learning using the basic concepts of Chemistry Education. Wicaksono (2020) said that the supporting aspects of science learning include (1) innovative problem / project based learning models, (2) using an approach that involves elements of science, technology and society, (3) improving skills with critical thinking, problem solving and creativity.

The first resource person at the workshop Dr. Zainuddin, M.Si explained the principles in online learning and the use of LMS in online learning (Fig 1). Based on a qualitative analysis, it was found that out of the 54 teachers who participated in the workshop activities at Nurul Fadhilah School, it was shown that $65 \%$ had never known about the Learning Management System application as shown in Fig. 2. LMSs that have been used in learning include Moodle, Edmodo, Google Classroom, and Schoology.

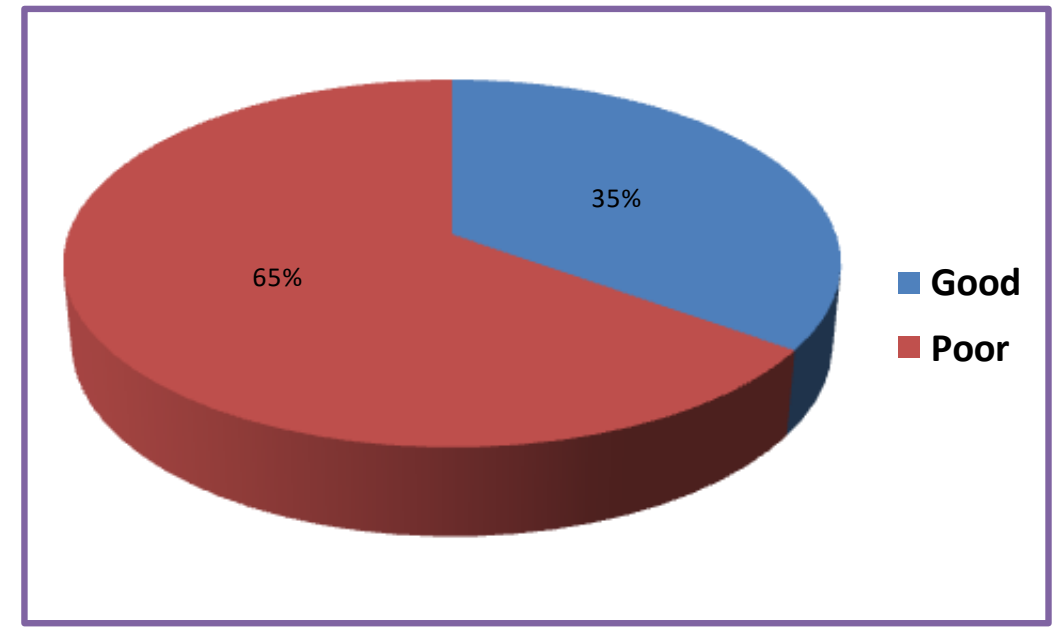

Fig 2. Initial response about LMS google classroom

LMS Moodle has been widely applied to learning activities in higher education, including the Moodle application in the human physiology anatomy course (Azis, 2017), Elementary Mathematics Learning Course in PGSD (Rijal and Sofiarni, 2019), Computer application introduction course (Rizal and Walidain, 2019) and others- 
other. Medan State University has also implemented online learning using a Moodlebased LMS application called the SIPDA application. Meanwhile, for elementary school to high school, LMS applications that are often used are Edmodo, Google Classroom or Schoology. However, not all schools are ready to use LMS in online learning, including the Nurul Fadhilah School.

The readiness of teachers in using the LMS application is important so that teachers can create, design and manage classes interactively using the features provided by the application, especially science teachers. The second speaker Dr. Sri Adelila Sari, M.Si. presents tips on science learning tips during the Covid-19 pandemic. The existence of advanced technology allows teachers to integrate the basic concepts of science learning using animated videos so that students can observe and observe science material through videos. Question and answer through interactive quizzes can be done to find out student feedback after watching the video. Mamin and Arif (2020) in his research stated that there was an increase in student learning outcomes in science courses using video tutorials.

Another study states that the advantages of learning videos are fun for students, able to provide real information, able to present different learning experiences such as animation (Hadi, 2017; Silaban, 2021). Dr. Sri Adelila Sari, M.Si also provides an example that is easy for teachers and students to apply for science learning. For example, by giving assignments to students to observe objects, living things around each student's house and making them in the form of videos to be collected through the LMS application. Another example in a home environment is that there are lots of items related to chemistry, for example students can be given assignments to read the composition contained in snacks, canned drinks, milk, detergents and others. Students can also be given the task of interviewing fried food sellers around their house and observing the frying process. Creating science-related assignments requires a basic understanding of science concepts, creativity and self-directed learning from science teachers.

Although learning is carried out online (distance), through a combination of technology, understanding the basic concepts of science material, teacher creativity in assigning assignments and students' independent learning abilities, science learning outcomes can be achieved well. Students have the experience to analyze, observe the natural surroundings even at home. In addition, parents of students also play a role in monitoring their children while studying at home. Collaboration between teachers, students and parents can create a more enjoyable atmosphere for online science learning. This workshop activity shows that there has been an increase in understanding of basic science concepts and an increase in the creativity of teachers in online science learning. In order for teachers to apply the knowledge gained, the LPPM team at the State University of Medan also provided training in the management of online science learning using LMS. The LMS chosen was Google 
Classroom, because this application has several features that will make it easier for teachers to manage their online learning activities (Hapsari and Pamungkas, 2019).

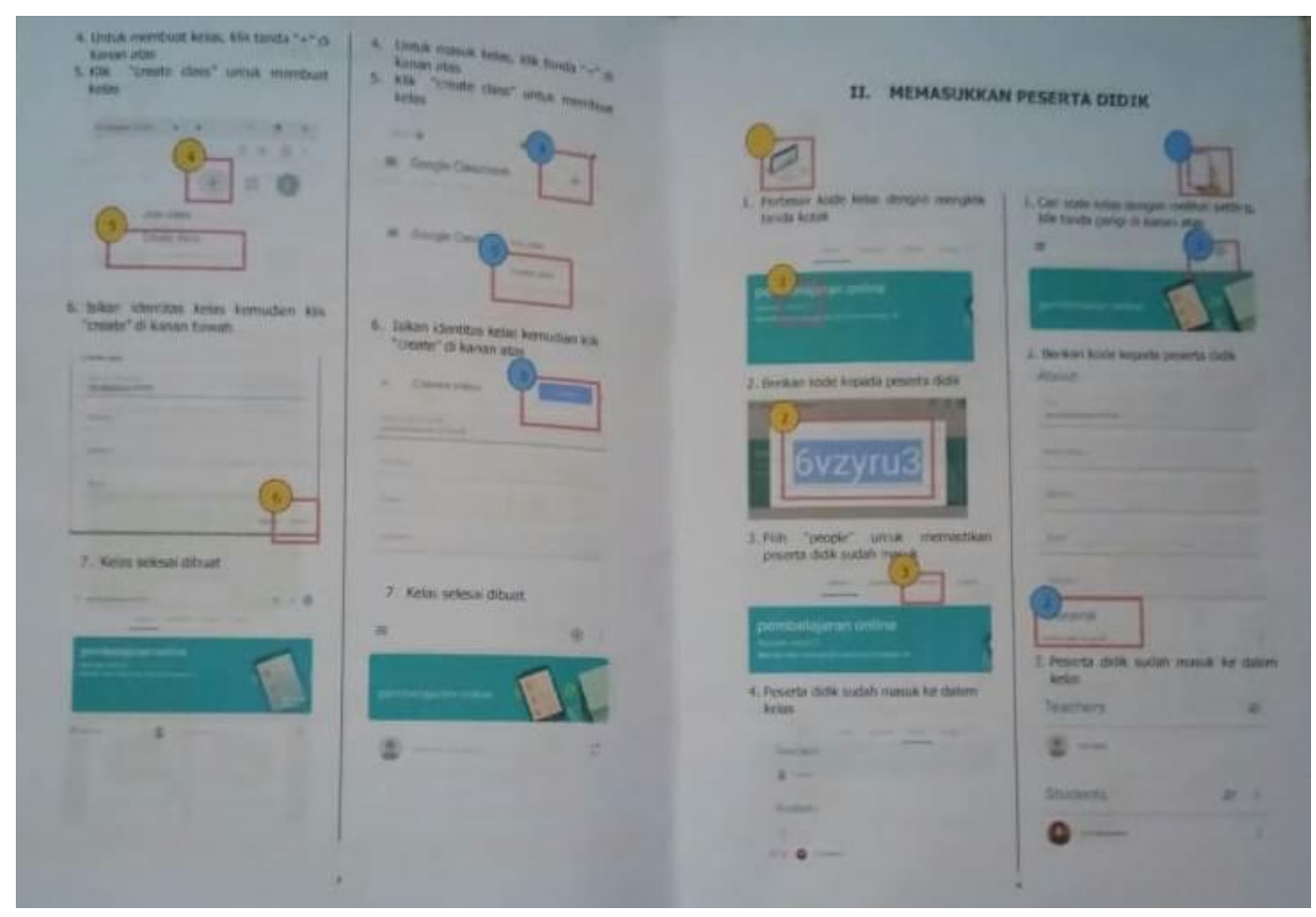

Fig 3. Google classroom guidebook

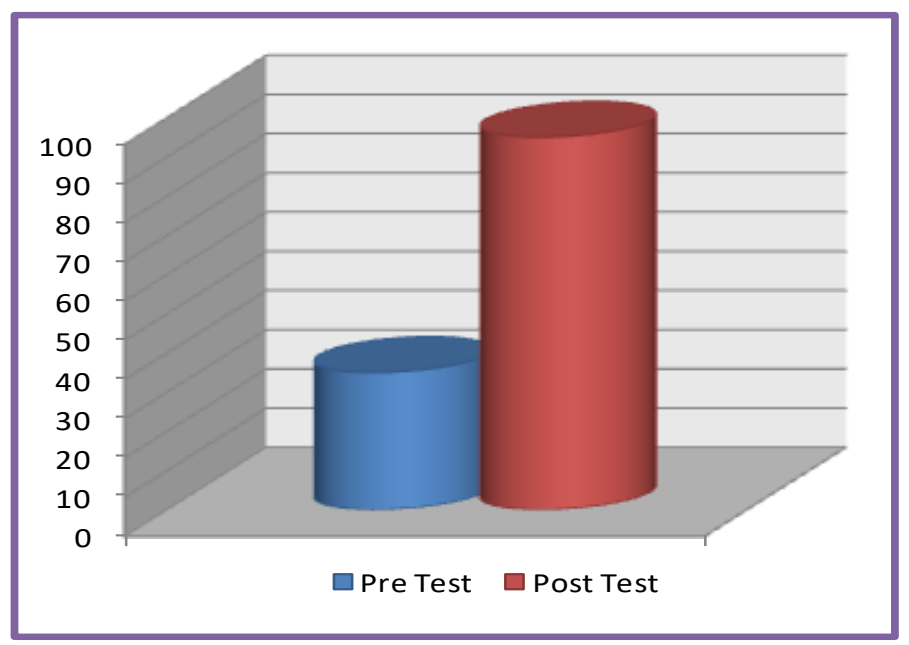

Fig 4. Initial and final LMS google classroom understanding responses comparison

Based on the results of the pretest, it is known that $65 \%$ of teachers do not know how to apply the LMS Google Classroom. So the Medan State University LPPM Team provided training on the use of LMS Google Classroom technology to provide experience for teachers in managing science learning online. Before the training, 
teachers were given a guidebook for the use of google classroom as teaching material as shown in Fig 3. Open the guide on how to use LMS google classroom for laptop (left side) and smartphone (right side) users so that it can accommodate the limitations of the teacher's technological devices. The results of the interview with the teacher indicated that the guidebook for using LMS in google classroom was easy to understand because it contained clear, sequential and complete instructions and pictures.

Based on the results of the posttest, it shows that there is an increase in teacher understanding in using the Google Classroom LMS become $95 \%$ as shown in Fig 4 . Through regular monitoring activities, it shows that as many as $80 \%$ of teachers have created, designed and managed classrooms interactively using Google Classroom LMS technology and have integrated the basic concepts of chemistry education in science learning. So that students are more happy and comfortable in learning online and are more disciplined in collecting assignments and teachers are more comfortable in managing and evaluating student assignments.

\section{Conclusion}

Science learning outcomes must be achieved even though teaching and learning activities are carried out online. Teacher readiness is a major factor in achieving this. Teachers at Nurul Fadhilah school have been provided with the management of online science learning using the basic concepts of chemistry education through workshops and the implementation of online science learning management using LMS Google Classroom. The results of these activities show an increase, as many as $80 \%$ of teachers have created, designed and managed classrooms interactively using Google Classroom LMS technology and have integrated the basic concepts of chemistry education in science learning. So that students are more happy and comfortable in learning online and are more disciplined in collecting assignments and teachers are more comfortable in managing and evaluating student assignments.

\section{Acknowledgment}

We would like to extend our sincere gratitude to BOPTN LPPM Universitas Negeri Medan Fund for valuable supports in funding this activity.

\section{References}

Azis, A. A. (2017). Pengembangan media E-learning berbasis Lms moodle pada matakuliah anatomi fisiologi manusia. Jurnal Pendidikan Biologi, 7(1), 1-8. DOI: 10.17977/um052v7i1p1-8

Bhagaskara, A. E., Afifah, E. N., \& Putra, E. M. (2021). Pembelajaran dalam Jaringan (DARING) Berbasis WhatsApp di SD Yapita. ZAHRA: Research and Tought Elementary School of Islam Journal, 2(1), 13-23. DOI: 10.37812/zahra.v2i1.183 
Hadi, S. (2017). Efektivitas penggunaan video sebagai media pembelajaran untuk siswa sekolah dasar. In Seminar Nasional Teknologi Pembelajaran dan Pendidikan Dasar 2017 (pp. 96-102).

Handayani, G. W., Maula, L. H., \& Uswatun, D. A. (2020). Analisis proses pelaksanaan pembelajaran daring di sekolah dasar pada masa pandemi Covid 19. DIKDAS MATAPPA: Jurnal Ilmu Pendidikan Dasar, 3(2), 166. DOI: 10.31100/dikdas.v3i2.649

Hapsari, S. A., \& Pamungkas, H. (2019). Pemanfaatan google classroom sebagai media pembelajaran online di Universitas Dian Nuswantoro. WACANA: Jurnal Ilmiah IImu Komunikasi, 18(2). DOI: 10.32509/wacana.v18i2.924

Harefa, N., Sinaga, M., \& Silaban, S. (2020). Students perception and interest on chemistry: Learning evaluation integrated quizziz media. Jurnal Pendidikan Kimia, 12(3), 143-150. DOI: 10.24114/jpkim.v12i3.21163

Hotimah, H., \& Muhtadi, A. (2018). Pengembangan multimedia pembelajaran interaktif IPA untuk meningkatkan pemahaman siswa pada materi Mikroorganisme SMP. Jurnal Inovasi Teknologi Pendidikan, 4(2), 201-213. DOI: 10.21831/jitp.v4i2.15047

Istiningsih, S., \& Hasbullah, H. (2015). Blended learning, trend strategi pembelajaran masa depan. Jurnal Elemen, 1(1), 49. DOI: 10.29408/jel.v111.79

Jamal, S. (2020). analisis kesiapan pembelajaran E-learning saat pandemi covid-19 di SMK Negeri 1 Tambelangan. Jurnal Nalar Pendidikan, 8(1), 16. DOl: 10.26858/jnp.v8i1.13561

Mamin, R., \& Arif, R. N. (2020). Efektivitas media pembelajaran video tutorial terhadap hasil belajar mahasiswa pada matakuliah IPA sekolah. Prosiding Seminar Nasional Lembaga Penelitian Universitas Negeri Makasar, pp. 348-352.

Prabowo, A. S., Conina, P. D. D., Afiati, E., \& Handoyo, A. W. (2020). Kesiapan guru dalam melaksanakan pembelajaran daring ditengah wabah covid-19. Jurnal Penelitian Bimbingan dan Konseling, 5(2), 9-12. DOI: 10.30870/jpbk.v5i2.10107

Rijal, A., \& Sofiarini, A. (2019). Pengembangan E-learning mata kuliah pembelajaran matematika SD berbasis aplikasi moodle di PGSD. Jurnal Basicedu, 3(4), 2071-2082. DOI: 10.31004/basicedu.v3i4.266

Rizal, S., \& Walidain, B. (2019). Pembuatan media pembelajaran E-learning berbasis moodle pada matakuliah pengantar aplikasi komputer Universitas Serambi Mekkah. Jurnal Ilmiah Didaktika: Media Ilmiah Pendidikan dan Pengajaran, 19(2), 178. DOI: 10.22373/jid.v19i2.5032

Silaban, S. (2021). Pengembangan program pengajaran. Medan: Yayasan Kita Menulis.

Wicaksono, A.G. (2020). Penyelenggaraan pembelajaran IPA berbasis pendekatan STEM dalam menyongsong era revolusi industri 4.0. LENSA (Lentera Sains): Jurnal Pendidikan IPA, 10(1), 54-62. DOI: 10.24929/lensa.v10i1.98 